\title{
Greek Sovereign Debt Crisis: Causes, Fiscal Adjustment Programs and Lessons for Croatia
}

\section{Mislav Brkić}

Croatian National Bank, Croatia

mislav.brkic@hnb.hr

\author{
CroEconSur \\ Vol. 18 \\ No. 1 \\ June 2016 \\ pp. 71-99
}

Received: March 8, 2016

Accepted: June 5, 2016

Review Article

doi:10.15179/ces.18.1.3

\section{Abstract}

This paper investigates the factors that have led to the Greek sovereign debt crisis in order to derive policy lessons for Croatia and other highly indebted countries. In the first years after euro adoption, it seemed that membership in the monetary union facilitated a catching-up process for Greece, given that it enjoyed high growth rates and a rapid convergence of per capita income. However, the global crisis has revealed that the previous economic expansion was an unsustainable process based on excessive inflow of debt-creating foreign capital. In this paper, it is argued that the government sector contributed the most to the rising vulnerability of the Greek economy. Data are presented showing that extensive government borrowing was the main factor behind the rapid accumulation of Greece's external debt, which made it highly vulnerable to external shocks. Besides the procyclical fiscal policy, some other factors also contributed to the overheating of economic activity in Greece. Hence, this paper 
reviews the literature that deals with the compression of peripheral countries' sovereign bond yields after the creation of the monetary union, the doubtful suitability of the ECB's expansionary policy stance from the perspective of then booming peripheral states, and the institutional shortcomings of the EMU. The main motivation of this paper is to identify the key roots of the Greek debt crisis in order to derive lessons for policy-makers in Croatia. Since the beginning of the recession in 2008, Croatia has seen a significant deterioration in fiscal fundamentals, with high public debt becoming the main source of macroeconomic vulnerability. Reducing the debt-to-GDP ratio has emerged as a key policy challenge that needs to be addressed in order to reduce the likelihood of a debt crisis.

Keywords: Greece, sovereign debt crisis, public debt, Croatia, monetary union

JEL classification: E52, E62, E65

\section{Introduction}

This paper discusses the factors that contributed to the escalation of the Greek sovereign debt crisis following the global crisis of 2008. An irresponsible fiscal policy in the pre-crisis period could be identified as the key source of Greece's marked vulnerability. High fiscal deficits were largely financed by capital inflows, so the government significantly contributed to the accumulation of foreign liabilities in that period. The road to the Greek debt crisis should also be viewed in the context of some external factors, which were outside the reach of domestic policy-makers. This paper therefore discusses issues such as the compression in sovereign yields of Greece and other peripheral member states prior to the establishment of the Economic and Monetary Union (EMU), inherent deficiencies in the EMU's institutional set-up, as well as the doubtful suitability of the single monetary policy for peripheral countries in the pre-crisis period. 
The main motivation of this paper is to identify the key roots of the Greek debt crisis in order to derive lessons for policy-makers in Croatia. After a six-yearlong recession, Croatia's public debt has increased dramatically and currently represents the key source of macroeconomic vulnerability. In view of Greece's unpleasant experience in the aftermath of the global financial crisis, it can be stated that Croatia, given the high level of government debt, could face great difficulties should a new episode of global crisis emerge.

The paper is structured as follows. The second section analyzes the factors that led to the Greek sovereign debt crisis and discusses the design and the impact of the fiscal adjustment programs, to which Greece committed in return for financial assistance from the IMF and the EU. The third section documents the significant deterioration of fiscal indicators for Croatia since the start of the recession, while the fourth section contains policy advice on how to avoid a materialization of a debt crisis in Croatia. The last section presents the main conclusions of the paper.

\section{Greek Sovereign Debt Crisis}

\subsection{Roots of Greece's Fiscal Problems}

In retrospect, one can say with certainty that the membership in the EMU has not been a successful story for Greece. In 2001, at the time of its entry into the EMU, Greece reported per capita income at 76 percent of the EU-15 average (Figure 1). During the following years, Greece experienced rapid economic growth that allowed it to reach 84 percent of the average EU-15 income per capita by 2008 .

However, following the escalation of the global financial crisis in late 2008, it was revealed that Greece's apparent economic convergence was mainly a result of an unsustainable expansion of domestic demand financed by heavy external borrowing. Due to a deep and prolonged recession, Greece has seen a persistent real divergence, with GDP per capita shrinking to only 67 percent of the EU-15 average by 2014 . 
Figure 1: GDP per Capita, Purchasing Power Standard (PPS), 2001-2014

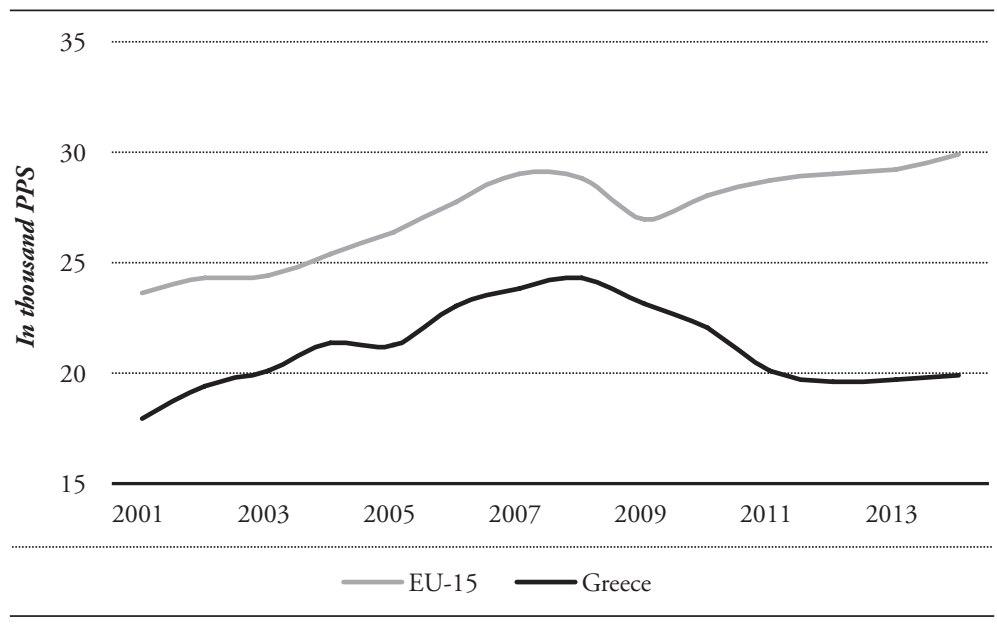

Source: Eurostat.

The macroeconomic indicators suggest that following the introduction of the euro, the Greek authorities did not exercise a prudent economic policy. In the years following euro adoption, Greece's general government deficit amounted to 6.7 percent of GDP on average, which deviated considerably from the fiscal data for other EMU countries (Figure 2). Intensive foreign borrowing reflected the expansion of public expenditure and total domestic demand, which led to growing fiscal vulnerabilities and a deterioration of competitiveness (IMF, 2010).

The unsustainable growth model was reflected in the emergence of pronounced external imbalances (Figure 3). Several authors argue that the widening of external imbalances in peripheral countries was primarily the result of a demand shock caused by abundant capital inflows from the core euro area countries (Gaulier and Vicard, 2012; Wyplosz, 2013). 
Figure 2: General Government Balance and Debt, 2001-2007, ESA 2010

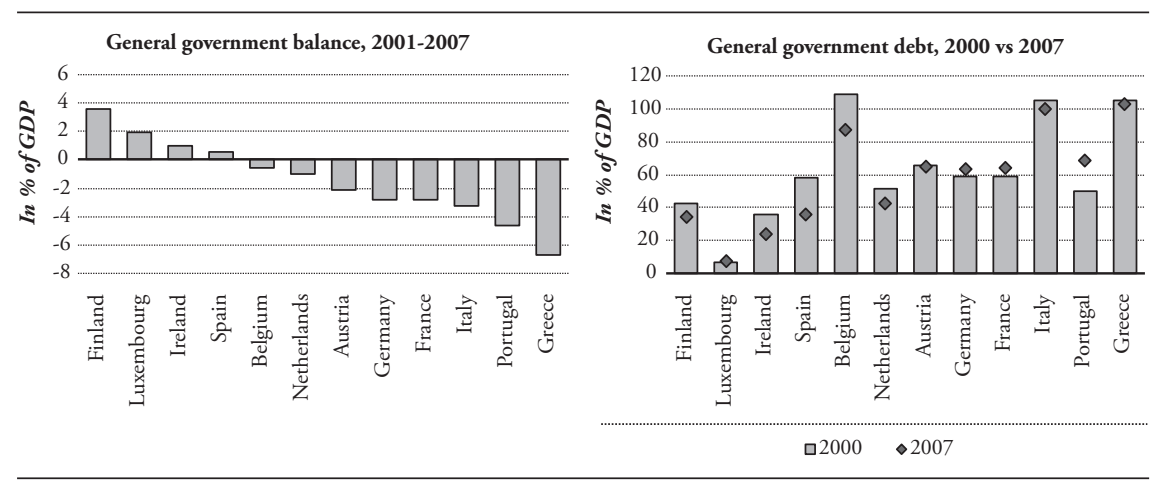

Source: Eurostat.

Figure 3: Greece - Balance of Payments and the International Investment Position, 2001-2007

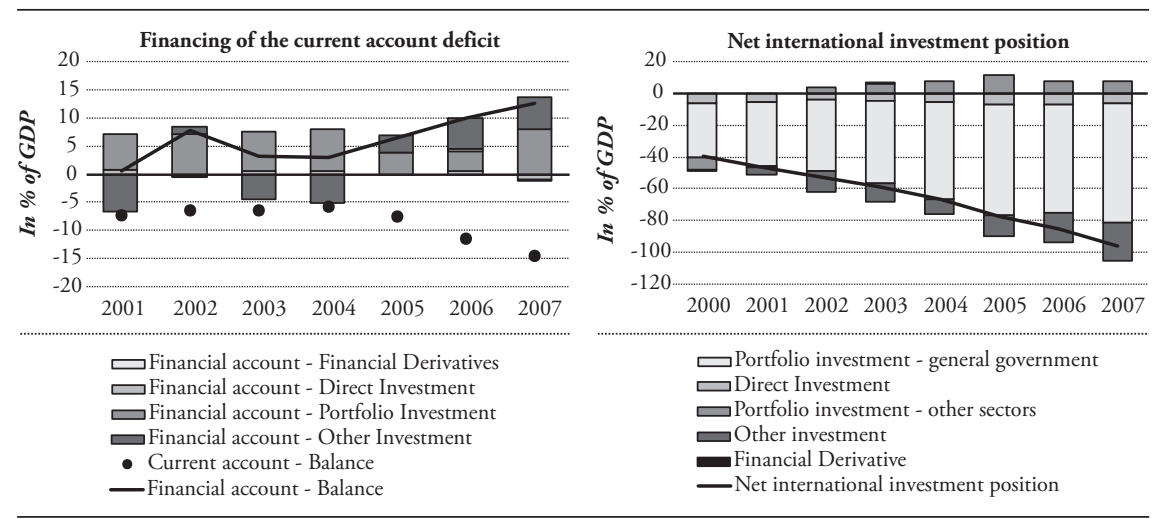

Source: Eurostat.

Unfavorable composition of the financial account surplus, with the dominance of debt-creating capital inflows, further exacerbated the vulnerability of the Greek economy (Figure 3). In contrast to other peripheral countries, where the key problem was private sector borrowing, the rapid rise in Greece's foreign debt was mainly related to government borrowing in the domestic market, where 
foreign investors accounted for a large share of total Greek debt holdings (Bank of Greece, 2008).

Other factors contributed to unsustainable economic trends in Greece, which were not under the direct influence of the Greek authorities. First, borrowing costs fell substantially as part of a general process of bond yield convergence prior to the start of the EMU. Many authors relate the drop in borrowing costs for peripheral countries to the carry trade activities of euro area banks (Hale and Obstfeld, 2014; Buiter and Sibert, 2005). Second, the low interest rate policy pursued by the ECB following the launch of the EMU was not entirely suitable for Greece, which was undergoing a rapid economic expansion (Arghyrou, 2006). Finally, at the time of the creation of the euro, EU policy-makers did not establish an appropriate coordination framework that would steer member states' economic policies and prevent the occurrence of severe imbalances (Brkić and Šabić, 2014).

\subsection{Greek Sovereign Debt Crisis and International Financial Assistance}

Although after joining the EMU Greece experienced robust economic growth, the government debt-to-GDP ratio did not decline due to the rapid increase in nominal debt caused by high budget deficits. Consequently, at the time of the escalation of the global financial crisis Greece was highly vulnerable, with the level of government debt above 100 percent of GDP. The already high deficit widened substantially due to economic contraction, causing the debt-toGDP ratio to reach 127 percent by the end of 2009. As a result, Greece faced tremendous pressures in financial markets, which were quickly transmitted to other vulnerable member states.

Greece virtually lost its access to financial markets in early 2010, forcing the Greek authorities to seek international financial assistance. In May 2010, Greece reached an agreement with the IMF and the EU on a financial arrangement 
worth 110 billion euro. The consolidation program comprised increases in VAT and excise taxes, a reduction in spending on public sector wages and pensions, layoffs in the public sector and a significant reduction in capital investment and social security expenses (IMF, 2010). However, the fiscal adjustment program supported by abundant financial assistance did not prove sufficient to stabilize public finances (Figure 4). When it became clear that the first adjustment program would not be completed, the Greek authorities engaged in negotiations on a new financial package. This time, the IMF and the EU insisted that Greece should first reduce its liabilities towards the private sector in order to enhance the sustainability of its debt (European Commission, 2012a). Following the completion of the debt reduction, a financial arrangement worth 130 billion euro was signed, with Greece committing to further fiscal consolidation. As it soon became obvious that Greece would not reach its fiscal targets, in November 2012 creditors agreed to reduce the interest burden and soften the required fiscal effort (European Commission, 2012b).

Figure 4: Greece - Real GDP and Fiscal Indicators, 2007-2015

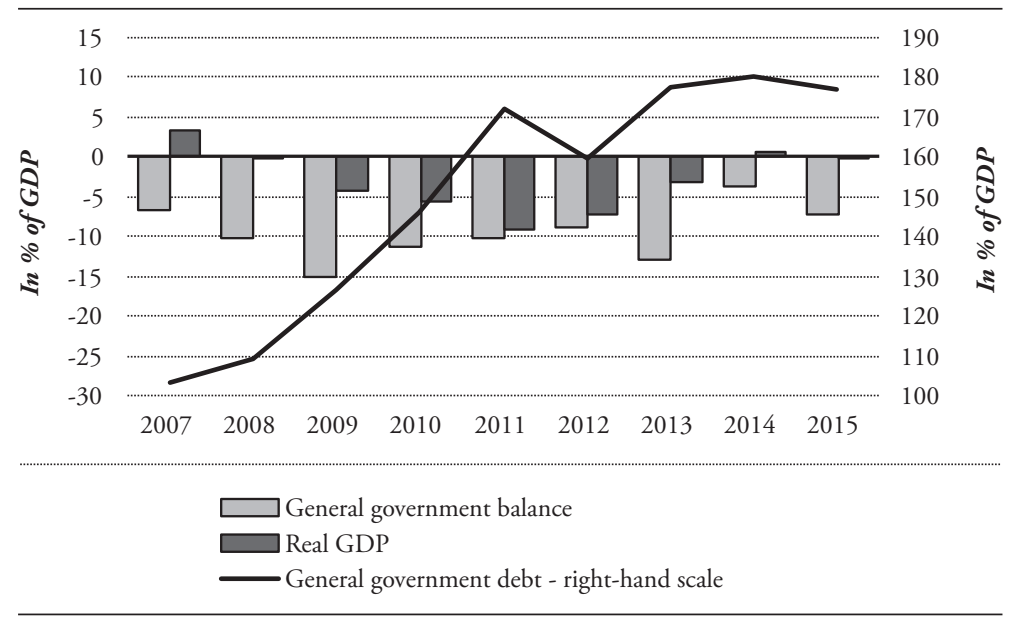

Source: Eurostat. 
During the implementation of the second bailout program, Greece began to show progress in terms of fiscal consolidation and macroeconomic stabilization (IMF, 2014). Nonetheless, political instability and weak public support for austerity measures reduced the likelihood of a successful completion of the adjustment program (IMF, 2014). In late 2014, when it became clear that the political party that was forcefully opposing the fiscal consolidation was set to win the parliamentary elections, uncertainty regarding Greece's prospects in the EMU increased, and the banking system faced considerable deposit outflows (ECB, 2015).

Since the agreement on the extension of the second bailout program was not reached in time, the second program expired in late June 2015. However, in August Greece made a deal with the EU on a third financial arrangement worth 86 billion euro (Council of the European Union, 2015). In return, the Greek authorities committed to achieve a considerable primary surplus over the medium term, carry out ambitious reforms of the pension system and of product and labor markets, recapitalize banks, as well as to accelerate the privatization process.

\subsection{Why Did the Economic Adjustment Programs in Greece Fail?}

There is little doubt that Greece had to consolidate its public finances given the considerable fiscal imbalances and the limited ability to borrow. However, the pace of fiscal consolidation envisaged in the economic adjustment programs was inadequate due to the cyclical position of the Greek economy at the time. In particular, the first program provided for consolidation measures amounting to 8 percent of GDP in the first year of its implementation, on the basis that a frontloaded fiscal consolidation would be necessary in order to boost investors' confidence. However, the harsh fiscal consolidation generated a strong additional burden to the already depressed economy, which consequently made the program self-defeating. 
Table 1: Greece-General Government Revenue and Expenditures, 2009-2011

\begin{tabular}{l|r|r|r|c}
\cline { 2 - 3 } & $\mathbf{2 0 0 9}$ & $\mathbf{2 0 1 0}$ & $\mathbf{2 0 1 1}$ & $\begin{array}{c}\text { Cumulative change 2010-2011, } \\
\text { in \%/in \% of GDP }\end{array}$ \\
\cline { 2 - 4 } & 128,412 & 118,586 & 112,282 & -12.6 \\
\hline $\begin{array}{l}\text { Total general government } \\
\text { expenditure }\end{array}$ & 92,422 & 93,253 & 91,077 & -1.5 \\
\hline $\begin{array}{l}\text { Total general government } \\
\text { revenue }\end{array}$ & -15.2 & -11.2 & -10.2 & 5.0 \\
\hline $\begin{array}{l}\text { General government } \\
\text { balance, in \% of GDP }\end{array}$ & 126.7 & 146.2 & 172.1 & 45.4 \\
\hline $\begin{array}{l}\text { General government debt, } \\
\text { in \% of GDP }\end{array}$ & 237,534 & 226,031 & 207,029 & -12.8 \\
\hline Nominal GDP & & & \\
\hline
\end{tabular}

Source: Eurostat.

By the end of 2011, the effects of the first program became noticeable, with government expenditures falling sharply compared to 2009 (Table 1). Despite substantial spending cuts, the general government deficit remained above 10 percent of GDP. This was primarily the result of a significant drop in nominal GDP, which fell by 13 percent in the period 2010-2011.

The IMF later admitted that the failure of the first adjustment program was partly due to the IMF staff's underestimation of the negative effects of the austerity measures on output growth (IMF, 2013). This is in line with Blanchard and Leigh (2013) who found that the IMF's forecasts for European countries between 2010 and 2011 were implicitly based on the fiscal multiplier of 0.5, while the actual level of the multiplier in this period was above one.

While staying in the EMU implies further fiscal consolidation with an uncertain outcome, this option seems to be more favorable for Greece than the alternative. Should Greece decide to leave the EMU and reintroduce the drachma, this would trigger severe disturbances in the Greek economy. First, the value of the national currency would probably fall sharply immediately after its introduction. Because of a probable lack of confidence in the new currency, economic agents might try to convert their assets to a credible foreign currency. As the foreign currency supply would likely be limited following the country's exit from the monetary 
union, an intensive currency depreciation might occur, generating inflationary pressures. Many countries have experienced episodes of currency crisis combined with high inflation rates, for instance Mexico in 1994-1995 (Krugman et al., 1999), Indonesia in 1997-1998 (Levinsohn, Berry and Friedman, 2003) and Argentina in 2002 (Dominguez and Tesar, 2007).

The banking system might also be severely affected if Greece decides to leave the EMU. Banks' asset quality might deteriorate, regardless of whether loans would be converted into the national currency or not. If the government decided to convert all euro loans to the new currency in order to ease the burden for borrowers, the real value of these loans might depreciate in line with the currency. On the other hand, if loans remained denominated in euro, borrowers might struggle to service their debts expressed in the appreciating foreign currency, leading to a surge in non-performing loans. Pressures on the quality of banks' assets might also stem from a potential recession and its negative effects on banks' asset quality. Banks might face severe difficulties on the liability side, as their euro-denominated liabilities would instantly become foreign currency debt, leaving them with large short foreign exchange positions. In such circumstances, national authorities could impose a conversion of euro liabilities to the new national currency in order to prevent simultaneous bank failures. Reinhart, Rogoff and Savastano (2003), based on the analysis of de-dollarization attempts in several highly dollarized economies, find that forcible conversions can cause dramatic capital outflows, while they are generally ineffective in promoting the domestic currency as a means of savings.

Disturbances in the real economy and the financial sector after leaving the EMU might generate substantial fiscal costs for Greece due to negative confidence and income effects and potential costs of banks' recapitalizations. A number of member states have experienced a negative feedback loop between public finances and the banking system over the past few years (Acharya, Drechsler and Schnabl, 2011; Mody and Sandri, 2011; Zoli, 2013). 


\section{Macroeconomic Vulnerabilities in Croatia in the Aftermath of Recession}

\subsection{Aggravation of Fiscal Imbalances}

Prior to the global crisis, Croatia enjoyed a robust economic expansion, supported by massive capital inflows and a favorable external environment. Although public spending grew rapidly, the fiscal deficit gradually declined, while the debt-to-GDP ratio was broadly stable at close to 40 percent of GDP (Figure 5). However, similar to the situation in Greece, when the crisis escalated, it soon became obvious that the apparent fiscal stability in the pre-crisis period was largely dependent on the high nominal GDP growth.

Figure 5: Croatia - Real GDP and Fiscal Indicators, 2003-2015

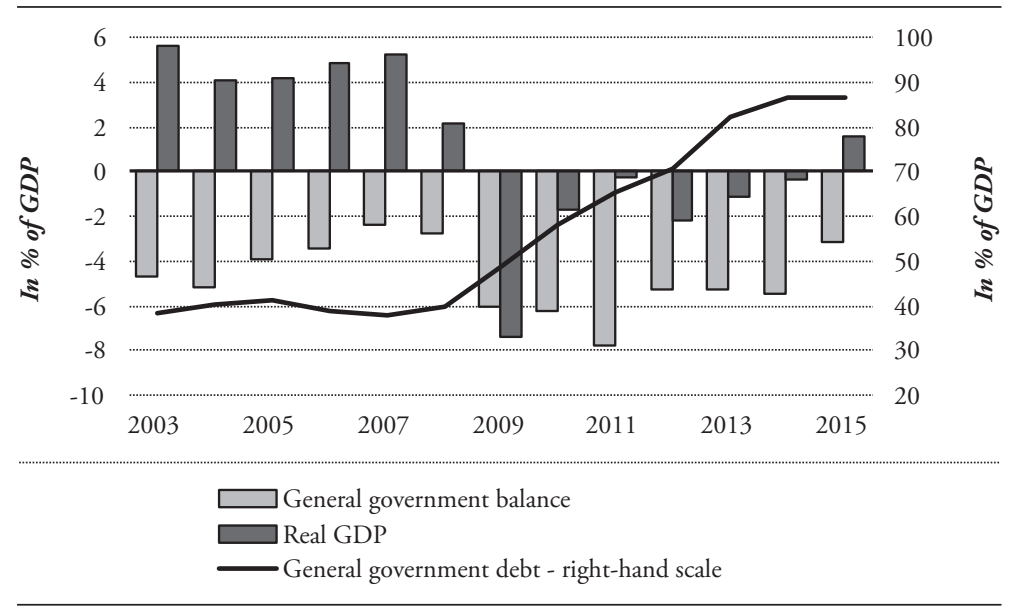

Source: Eurostat.

In an environment of prolonged recession, Croatia has reported high fiscal deficits since 2009, which have led to a rapid build-up of general government debt (Figure 5). Mainly due to intensive government borrowing, the debt ratio reached 85 percent of GDP at the end of 2014, compared with only 37 percent of GDP in 2007. The other part of the overall increase in government debt is a 
result of the transition to a new statistical methodology, ESA 2010, according to which several highly indebted state-owned companies had to be reclassified to the general government sector (CNB, 2014).

\subsection{Composition of the Public Debt as a Source of Vulnerability}

The currency composition of the debt reveals that Croatia's public finances are heavily exposed to currency risk. At the end of 2015, the external component accounted for 40 percent of total debt, and almost the same percentage was related to domestic debt indexed to foreign currency. Therefore, close to 80 percent of the total outstanding debt is directly exposed to exchange rate volatility. The sensitivity of public finances to exchange rate movements is a challenge for other emerging market economies as well (IMF, 2004). Many of them rely heavily on external borrowing in foreign currencies due to limited domestic supply of funds, and due to a lack of confidence of foreign investors in their national currencies. Intensive borrowing in foreign currency generates a currency mismatch, which represents a major constraint for policy-makers (Eichengreen, Hausmann and Panizza, 2003).

Having a large external component in the debt implies that foreign investors hold a significant part of the outstanding government debt instruments. This is a source of refinancing risk for Croatia, considering that foreign investors typically establish much weaker relationships with the government compared to domestic institutional investors (Das et al., 2010). It is worth noting the case of Japan, whose government enjoys low borrowing costs even though budget deficits are stubbornly high and the public debt has reached unprecedented levels of close to 250 percent of GDP. Lam and Tokuoka (2011) explain this phenomenon by the fact that Japan's debt securities are predominantly owned by domestic financial institutions that are committed to investing in government securities regardless of the size of fiscal imbalances. 
Unlike Japan, advanced EU member states generally experience high participation of foreign investors in domestic sovereign debt markets but this does not entail high risks for these countries due to their liquid sovereign debt markets. On the other hand, in emerging market countries the capital markets are generally relatively shallow, so a high participation of foreign investors can be a major source of risk (Jeanneau and Tovar, 2007). Confirmation of this can be found in the episode of sudden capital outflows from emerging market economies in mid2013, which was triggered by the Federal Reserve Board's announcement about a possible monetary tightening in the US.

The low participation of foreign investors in the Croatian financial market reduces the risk of destabilizing capital flows, which facilitates the implementation of a stable exchange rate policy (IMF, 2015a). Nevertheless, taking into account the large government debt and the high external financing needs, the probability that Croatia in some scenario could confront refinancing issues like Greece is far from negligible.

\subsection{Indicators of External Performance}

In addition to experiencing negative trends, such as the decline in economic activity and employment coupled with a steep rise in public debt, Croatia has recently significantly reduced its external imbalances. After a long period of large current account deficits and a rapid build-up of external debt, Croatia has experienced a gradual rebalancing of the current account, and a mild improvement in the net international investment position (Figure 6). The improvement in the current account balance was at first driven by a contraction of imports caused by the recession, but more recently it has also been supported by dynamic export growth $(\mathrm{CNB}, 2015)$. The unwinding of external imbalances indicates that the period of unsustainable economic expansion based on excessive debt-creating capital inflows is over, which may suggest that the sensitivity of the economy to capital flows is now lower. Yet, as noted in this article, the vulnerability of public 
finances has increased in the meantime, so it cannot be argued that Croatia is now more resilient to external shocks than it was in 2008.

Figure 6: Croatia - Balance of Payments and the Net International Investment Position

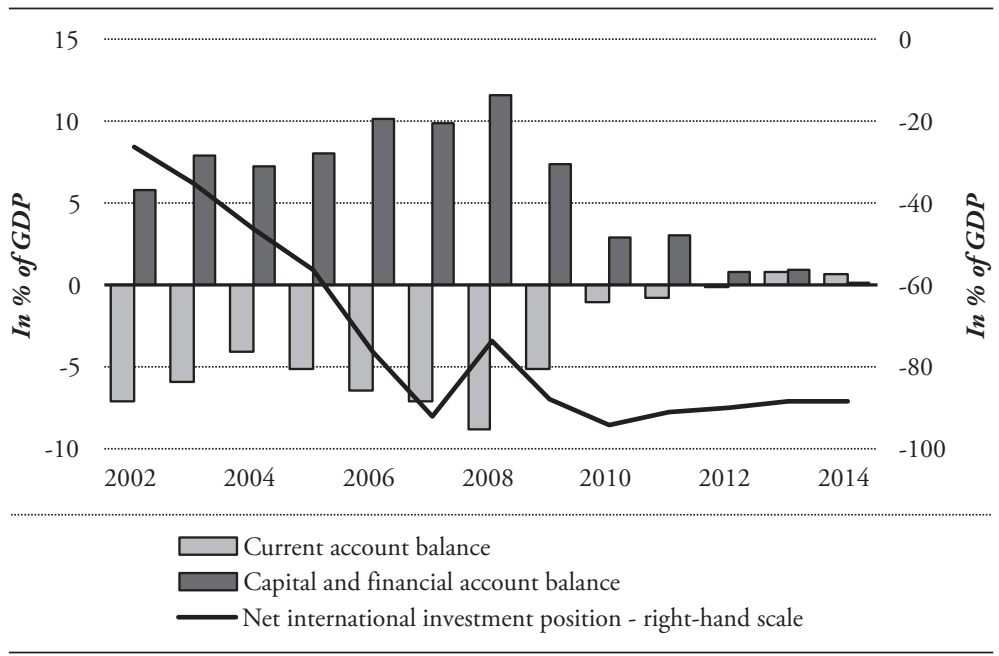

Source: Croatian National Bank.

\subsection{Did Croatia Benefit from Not Being Part of the EMU Prior to the Crisis?}

If Croatia had managed to enter the EU before the crisis, this would perhaps have allowed it to attract more FDI into manufacturing activities and thus expand its export potential. The experience of countries such as Czech Republic, Slovakia, Poland and Hungary illustrates that early EU membership facilitated integration into European value chains (Deutsche Bank, 2014). However, these countries have certain advantages relative to Croatia due to their geographical proximity to Germany and Austria, the main providers of foreign direct investment, and also due to their previously established capacities in the automotive industry (Radošević and Rozeik, 2005). Therefore, one can assume that even if Croatia had entered the EU in an earlier phase, the structure of capital inflows would still have been unfavorable. 
Based on this assumption, it can be argued that Croatia benefited from not being in the EMU prior to the crisis. There are two main arguments for this claim. First, by being a member of a credible monetary union, Croatia would have been an even more attractive destination for foreign capital, which might have resulted in a more intensive accumulation of imbalances. In the first half of the 2000s, the yields on Croatian government bonds were higher than the sovereign yields of the peripheral euro area countries (Figure 7). Despite the growing optimism of investors regarding the economic outlook and the start of the EU accession process (CNB, 2006), Croatia did not experience an acceleration of inflows to the domestic sovereign debt market. The low attractiveness of government debt instruments can be explained by the relative shallowness of the Croatian financial market and, at that time, the still incomplete openness of the capital account ${ }^{1}$.

Figure 7: Long-Term Sovereign Bond Yields Spreads, 2001-2015

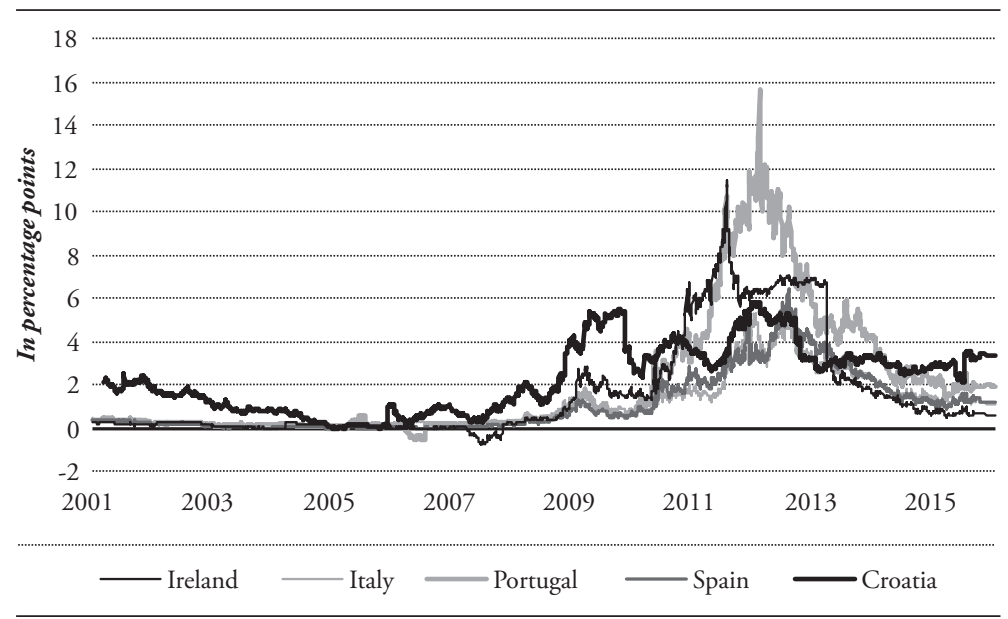

Sources: Bloomberg and Eurostat.

The second argument relates to the fact that Croatia, as a pre-accession candidate state, was able to conduct discretionary monetary and macroprudential policies to contain the adverse effect of excessive capital inflows. In particular, the 
Croatian National Bank (CNB) was able to apply a wide range of monetary and macroprudential instruments to slow down the banks' external borrowing that fuelled domestic demand (CNB, 2009). One of the main instruments used to contain excessive bank borrowing was the marginal reserve requirement, which obliged banks to deposit up to 55 percent of each additional foreign borrowing to a low-yield account at the CNB. In addition, the CNB required the banks to hold liquid foreign currency assets covering around a third of their total FX liabilities. In this way, the CNB raised the cost of foreign funding sources, while also establishing considerable foreign currency liquidity buffers.

This later allowed the CNB to intervene in the height of the global financial crisis to alleviate the funding pressures in the economy. Specifically, by abolishing the marginal reserve requirement, relaxing the provisions on liquid FX assets and by adjusting the rate and the currency composition of the general reserve requirement, the central bank injected a substantial amount of foreign currency liquidity into the economy ${ }^{2}$. This mitigated the liquidity pressures faced by banks, while also allowing the government to borrow from domestic banks (Rohatinski, 2015). Meanwhile, Greece and several other member states, which did not have sufficient domestic reserves, had no choice but to seek international financial assistance ${ }^{3}$.

\section{How Can Croatia Avoid the Greek Scenario?}

The most important lesson of the Greek debt crisis is that the Croatian government should focus on reducing the excessive debt-to-GDP ratio, which currently represents a major source of risk for the economy. If this problem is not solved in time, the sensitivity of public finances and the entire economy to external shocks will remain elevated, implying also a high likelihood of a future sovereign debt crisis. Moreover, if Croatia were to face another episode of strong

2 Only from October 2008 to February 2009, the CNB released foreign currency liquidity buffers amounting to 3.5 billion euro, which was equal to 7.3 percent of GDP.

3 Between 2008 and 2011, six member states requested financial assistance from the IMF and the EU: Hungary, Latvia, Romania, Greece, Ireland and Portugal. 
capital inflows in the future, policy-makers should use all instruments provided by the EU's upgraded economic governance framework to prevent an excessive build-up of macroeconomic imbalances.

\subsection{The Importance of Reducing the Debt-to-GDP Ratio}

Over the past few years, and especially since the beginning of 2014, asset prices in global financial markets have significantly increased, driven by the unprecedented monetary easing in the advanced economies aimed at stimulating economic recovery. Under these conditions, the yields on fixed income assets have decreased considerably, including the yields on lower rated instruments (IMF, 2015b). Accordingly, Croatia registered a notable decline in required market yields (Figure 8). However, this low yield environment also has certain negative effects, given that it generates a belief among policy-makers that fiscal consolidation efforts and structural reforms are no longer necessary to stimulate investors' demand and achieve low borrowing costs.

Figure 8: Long-Term Sovereign Bond Yields

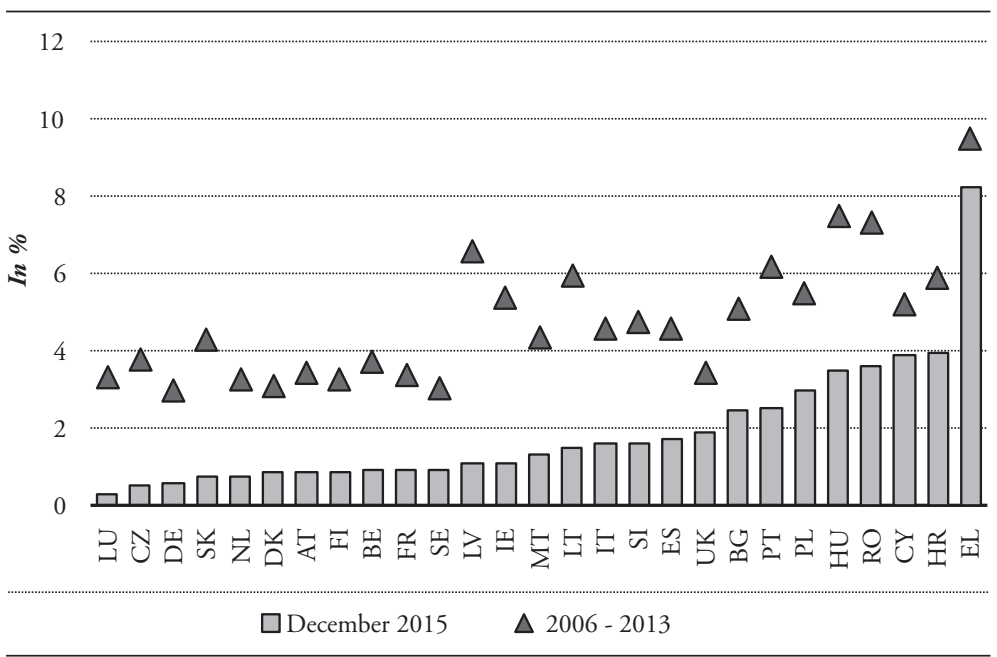

Source: Eurostat. 
Although the bond yields have declined in line with global trends, which temporarily alleviates refinancing risk, investors continue to assess Croatia as a more risky country compared to its peers (Figure 8). The existing gap in borrowing costs implies that Croatia has less credibility in the financial markets, which in turn makes it more vulnerable to sudden changes in global risk aversion. Kunovac (2013) argues that due to its weak fundamentals, Croatia is among the countries that are most vulnerable to external shocks.

Figure 9: Croatia - General Government Debt vs. the Market Yield on 10y Sovereign Bonds

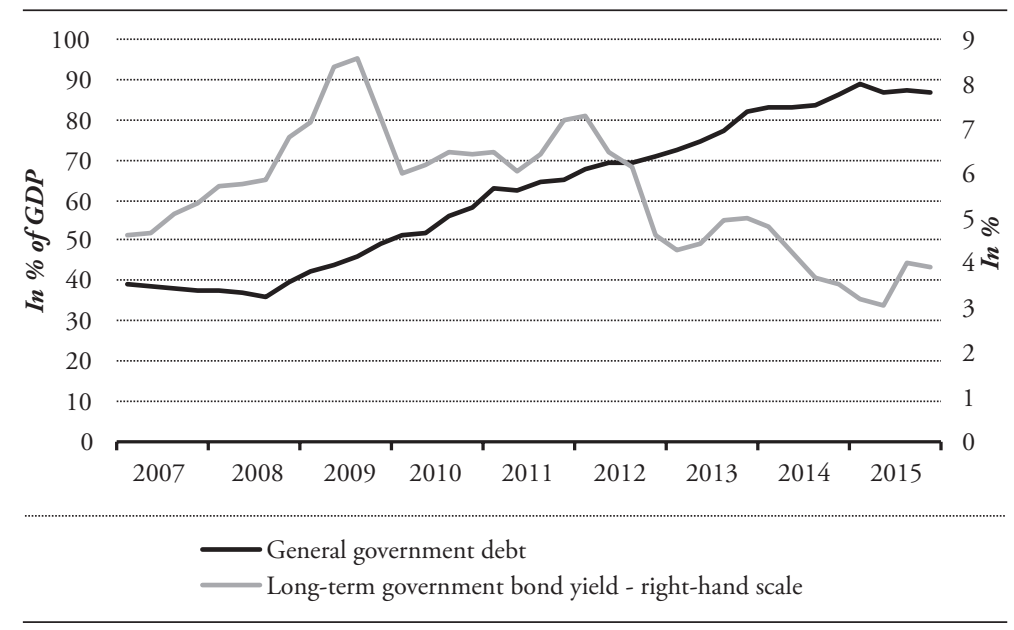

Source: Eurostat.

In conclusion, the steep decline in Croatian bond yields is not driven by fundamentals, but by temporary factors that are set to abate over the medium term (Figure 9). The gradual normalization in the monetary policies of the leading central banks will probably lead to an increase in risk-free interest rates, which would probably result in more expensive financing for risky borrowers. Therefore, policy-makers in Croatia should immediately start to address existing fiscal vulnerabilities, if they want to avoid a considerable rise in the debt burden after global liquidity conditions tighten. 
At the onset of the global financial crisis in 2008, Croatia's debt-to-GDP ratio was lower than the debt ratios for advanced member states, and similar to the levels reported by some peer countries. Currently, it is higher than the average values for both the old and the new member states (Figure 10). As soon as economic recovery gains traction, policy-makers should focus on an ambitious fiscal consolidation in order to put the debt-to-GDP ratio on a firm downward $\mathrm{path}^{4}$. On the other hand, stabilizing the debt ratio at the current high level would not be enough to insulate the public finances from negative shocks. In particular, Greece's disastrous experience demonstrates that a country with a high level of debt and a strong dependence on foreign borrowing can experience a severe debt crisis if a strong negative shock initiates a recession and hampers the government's ability to borrow.

Figure 10: Government Debt, 2007 and 2015

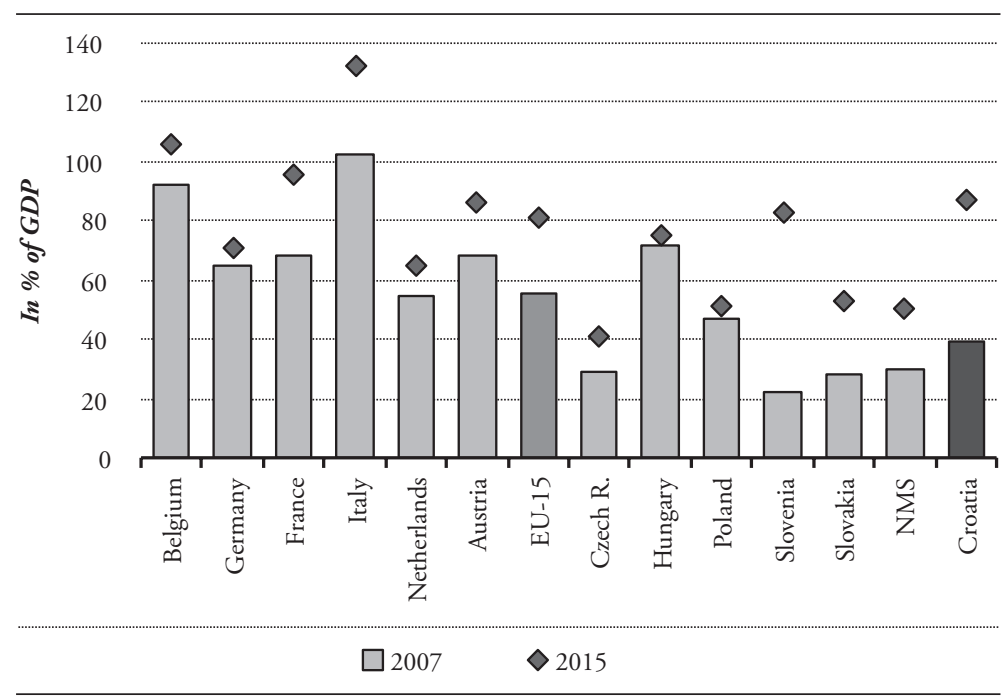

Note: Greece and Cyprus were excluded when calculating averages for EU-15 and NMS Source: Eurostat.

4 Mihaljek (2009) argues that Croatia's debt-to-GDP ratio was already high at the onset of the global financial crisis when it stood at around 40 percent of GDP. This author points out that Croatia was not able to adopt a fiscal stimulus because in the environment of already high fiscal imbalances and generally weak macroeconomic fundamentals such policy intervention would lead to further deterioration in the investors' sentiment. 
Despite the fact that it released part of its foreign currency liquidity reserves as a countercyclical response to the global crisis, the $\mathrm{CNB}$ still has large reserves that could be used in a period of stress. The problem is that the capacity of the commercial banks to alleviate the government's funding problem is now lower than in 2008. In particular, the willingness of domestic banks to provide a significant amount of funding to the government could be limited due to their high exposure to the government after several years of substantial financing. Therefore, if a new shock hits the economy, the Croatian government could experience a debt crisis, because its access to international markets could be virtually lost as the required yield might reach prohibitively high levels, while the domestic banking system possibly would not be able to provide sufficient funding.

A reduction in the excessive debt-to-GDP ratio could be achieved through a combination of fiscal consolidation measures and measures to stimulate economic recovery. It would be important to find the appropriate pace and structure of fiscal consolidation5. Eyraud and Weber (2013) find that if fiscal consolidation is pursued during a recession, it may further depress the economic activity and thereby contribute to the deterioration in the debt-to-GDP ratio. In contrast, if a large part of the consolidation effort is implemented during the recovery phase, when the fiscal multiplier is lower, the likelihood of success is higher. The Greek case supports the claim that a frontloaded consolidation can become selfdefeating if carried out in a recessionary environment. Croatia has also struggled to address the rapid accumulation of government debt during the six-year-long recession. In 2015, however, a moderate consolidation effort supported by the ongoing recovery of both domestic and external demand generated positive fiscal effects and the deficit shrank from 5.5 percent to 3.2 percent of GDP (European Commission, 2016).

5 Alesina, Favero and Giavazzi (2012) find that consolidation programs based on expenditure cuts are generally more effective in enhancing fiscal sustainability than the ones that rely predominantly on tax increases. The main reason is that tax increases usually have a strong and long-lasting negative impact on business confidence and private investment, while expenditure cuts tend to have only minor effects on output. 
Discipline on the side of policy-makers is a key factor in ensuring that a cyclical improvement in fiscal revenues leads to a reduction of fiscal imbalances, rather than to a further rise in public expenditures. In line with Alesina, Favero and Giavazzi (2012), the consolidation program should mainly rely on reducing spending on items such as intermediate consumption and the public sector wage bill, which have remained high despite significant consolidation in recent years. In contrast, public expenditures that are deemed to have a positive effect on potential growth, such as education spending or capital investments, which have been reduced considerably in recent years, should be excluded from further spending cuts or even increased.

\subsection{Entry into the EMU as a Strategic Policy Goal}

In the previous section I argued that Croatia benefited from not being a member of the EMU prior to the financial crisis, primarily because as a non-euro area country it was able to conduct discretionary monetary and macroprudential policies to slow down the accumulation of imbalances. However, in the aftermath of the crisis the economic coordination framework in the EMU has been significantly upgraded, and this should reduce the likelihood of member states experiencing unsustainable economic expansions like that in Greece (Brkić and Šabić, 2014). Assuming that the Croatian authorities will pursue responsible fiscal and structural policies in accordance with the demands of the new coordination mechanisms, the cost of abandoning monetary sovereignty should not be too large.

The elimination of the currency risk would be the biggest advantage of EMU membership. It was pointed out above that Croatia's public finances are heavily exposed to currency risk. Pursuing a stable exchange rate policy in Croatia is not only beneficial from the perspective of public finances, but it is also an important instrument for protecting other economic sectors in the highly euroized economy. The specificity of the Croatian banking system is the high share of 
foreign currency deposits in the total liabilities of banks, which is reflected in the high proportion of foreign currency loans on the asset side. Furthermore, given the dominance of foreign currency deposits on the liability side, exchange rate stability is necessary in order to minimize the possibility of a bank run ${ }^{6}$. Several studies show that exchange rate stability is often a policy priority in countries like Croatia, where domestic sectors heavily rely on foreign currency borrowing (Calvo and Reinhart, 2000; Hausmann, Panizza and Stein, 2001). In addition to safeguarding the domestic sectors against the currency risk, a stable exchange rate policy may serve other purposes, such as providing an anchor for price stability and facilitating international trade and investment (Dornbusch, 2001). This is especially relevant for Croatia and other emerging market economies that are highly economically integrated with a single currency area.

Considering the government's high exposure to the currency risk, as well as the direct and indirect exposure of other economic sectors, the adoption of the euro seems like a legitimate strategic goal for Croatia. However, due to its dismal macroeconomic performance, Croatia is currently not able to meet the fiscal criteria for euro adoption. In order to improve Croatia's prospects to join the EMU, the government should focus on reducing the fiscal vulnerabilities, as well as on addressing the macroeconomic imbalances that have been identified as most problematic for Croatia in the context of the EU's Macroeconomic Imbalances Procedure (MIP).

\section{Conclusion}

The analysis of macroeconomic performance of Greece provided in this paper suggests that the deep recession and debt crisis experienced by the country in recent years are mainly related to irresponsible economic policies in the precrisis period. In particular, domestic sectors took advantage of affordable market

6 Chang and Velasco (1998) note that the central banks that pursue a stable exchange rate policy face an unpleasant dilemma if the banking system suffers a significant outflow of foreign currency deposits. In such circumstances they have two options: to do nothing and thus jeopardize the solvency of the banking system, or release part of international reserves to banks, but risk a possible collapse of the stable exchange rate regime. 
financing in the aftermath of euro adoption, with the government sector being particularly active in this regard. The heavy inflow of foreign capital fuelled domestic demand, leading to rising fiscal vulnerabilities, a deterioration of competitiveness and a rapid build-up in macroeconomic imbalances.

In contrast to Greece, Croatia has managed to withstand the global financial crisis and subsequent prolonged recession without relying on international financial assistance. Among the factors that contributed to the relative resilience of Croatia, it is worth mentioning the central bank's prudent countercyclical response to the crisis and a moderate initial level of public debt. In particular, by releasing part of the previously established foreign currency liquidity reserves, the central bank eased the liquidity problems in the banking system, which also allowed the government to borrow from domestic banks and thus weather the period of limited access to international markets. Although fiscal policy in the pre-crisis period in Croatia was largely procyclical, with the onset of the global crisis the government debt ratio was still relatively moderate, which allowed Croatia to withstand a period of high cyclical deficits without undermining debt sustainability.

Croatia's fiscal fundamentals have deteriorated substantially in the environment of a deep and prolonged recession, with the debt-to-GDP ratio reaching 85 percent by the end of 2014. Reducing the excessive debt-to-GDP ratio should be a policy priority in order to address refinancing risk and thus minimize the likelihood of a debt crisis. Greece's experience demonstrates that a country with a high level of government debt and strong dependence on foreign borrowing may find itself in a severe debt crisis if a strong negative shock initiates an economic downturn and hampers the government's ability to borrow in international financial markets.

The required debt reduction could be achieved through a combination of fiscal consolidation measures and measures to stimulate economic recovery. In that regard, it would be extremely important to find an appropriate pace and structure 
of fiscal consolidation. The Greek case clearly shows that a strong frontloaded consolidation can become self-defeating if it is carried out in a recessionary environment. In contrast, as confirmed by a marked improvement in Croatia's fiscal balance in 2015, a more moderate consolidation effort supported by a positive growth environment can provide the necessary improvement in public finances. Discipline on the side of policy-makers is the key factor to ensure that a cyclical improvement in fiscal revenues leads to deficit reduction, rather than to a further rise in public spending.

In addition to the refinancing risk, Croatia's public finances are also very exposed to the risk of currency depreciation, since more than three quarters of total debt are denominated in or indexed to foreign currencies. By joining the EMU, which will be possible only after the fiscal imbalances are properly addressed, Croatia's sensitivity to currency risk would be largely eliminated. Nevertheless, Greece's experience warns that membership in the monetary union also carries some risks for the economy, especially the risk of excessive capital inflows and the related overheating of the economy. In order to avoid an unsustainable expansion in the period following EMU entry, Croatian policy-makers should pursue a prudent fiscal policy and apply the available macroprudential instruments to contain the borrowing cycle and prevent the accumulation of harmful imbalances. 


\section{Literature}

Acharya, Viral V., Itamar Drechsler and Philipp Schnabl, 2011, "A Pyrrhic Victory? - Bank Bailouts and Sovereign Credit Risk", NBER Working Paper, No. 17136, June, Cambridge, MA: National Bureau of Economic Research.

Alesina, Alberto, Carlo Favero and Francesco Giavazzi, 2012, "The Output Effect of Fiscal Consolidations”, NBER Working Paper, No. 18336, August, Cambridge, MA: National Bureau of Economic Research.

Arghyrou, Michael G., 2006, "Monetary Policy Before and After the Euro: Evidence from Greece", Cardiff Economics Working Papers, No. E2006/23, November, Cardiff: Cardiff University.

Bank of Greece, 2008, Annual Report 2007, Athens: Bank of Greece.

Blanchard, Olivier and Daniel Leigh, 2013, "Growth Forecast Errors and Fiscal Multipliers”, IMF Working Papers, No. 13/1, January, Washington, DC: International Monetary Fund.

Brkić, Mislav and Ana Šabić, 2014, "Framework for Monitoring Macroeconomic Imbalances in the European Union - Significance for Croatia", Surveys, No. 17, October, Zagreb: Croatian National Bank.

Buiter, Willem H. and Anne C. Sibert, 2005, "How the Eurosystem's Treatment of Collateral in its Open Market Operations Weakens Fiscal Discipline in the Eurozone (and What to Do about It)", CEPR Discussion Paper, No. 5387, London: Centre for Economic Policy Research.

Calvo, Guilermo A. and Carmen M. Reinhart, 2000, "Fear of Floating", NBER Working Paper, No. 7993, November, Cambridge, MA: National Bureau of Economic Research.

Chang, Roberto and Andres Velasco, 1998, "Financial Crises in Emerging Markets", NBER Working Paper, No. 6606, June, Cambridge, MA: National Bureau of Economic Research. 
Council of the European Union, 2015, Eurogroup Statement on the ESM Programme for Greece, Brussels: Council of the European Union.

Croatian National Bank (CNB), 2006, Annual Report 2005, Zagreb: Croatian National Bank.

Croatian National Bank (CNB), 2009, Annual Report 2008, Zagreb: Croatian National Bank.

Croatian National Bank (CNB), 2014, Bulletin 209, Zagreb: Croatian National Bank.

Croatian National Bank (CNB), 2015, Bulletin 220, Zagreb: Croatian National Bank.

Das, Udaibir S., Michael Papapioannou, Guilherme Pedras, Faisal Ahmed and Jay Surti, 2010, "Managing Public Debt and Its Financial Stability Implications", IMF Working Papers, No. 10/280, December, Washington, DC: International Monetary Fund.

Deutsche Bank, 2014, "CEE: Fit for the Next Decade in the EU”, EU Monitor, Deutsche Bank Research, April, Frankfurt: Deutsche Bank.

Dominguez, Kathryn M. E. and Linda L. Tesar, 2007, "International Borrowing and Macroeconomic Performance in Argentina”, NBER Chapters, in Sebastian Edwards, ed., Capital Controls and Capital Flows in Emerging Economies: Policies, Practices and Consequences, pp. 297-348, Chicago, IL: University of Chicago Press. http://dx.doi.org/10.7208/chicago/9780226184999.003.0008

Dornbusch, Rudi, 2001, “Fewer Monies, Better Monies”, NBER Working Paper, No. 8324, June, Cambridge, MA: National Bureau of Economic Research.

Eichengreen, Barry J., Ricardo Hausmann and Ugo Panizza, 2003, "Currency Mismatches, Debt Intolerance and Original Sin: Why They Are Not the Same and Why it Matters", NBER Working Paper, No. 10036, October, Cambridge, MA: National Bureau of Economic Research. 
European Central Bank (ECB), 2015, Financial Stability Review, May, Frankfurt: European Central Bank.

European Commission, 2012a, The Second Economic Adjustment Programme for Greece, Occasional Paper, No. 94, Brussels: European Commission.

European Commission, 2012b, The Second Economic Adjustment Programme for Greece, First Review, Occasional Paper, No. 123, Brussels: European Commission.

European Commission, 2016, European Economic Forecast - Spring 2016, Brussels: European Commission.

Eyraud, Luc and Anke Weber, 2013, "The Challenge of Debt Reduction during Fiscal Consolidation”, IMF Working Papers, No. 13/67, March, Washington, DC: International Monetary Fund.

Gaulier, Guillaume and Vincent Vicard, 2012, "Current Account Imbalances in the Euro Area: Competitiveness or Demand Shock?", Quarterly Selection of Articles - Bulletin de la Banque de France, 27(Autumn), pp. 5-26.

Hale, Galina and Maurice Obstfeld, 2014, "The Euro and the Geography of International Debt Flows", Working Paper, No. 2014-10, December, San Francisco, CA: Federal Reserve Bank of San Francisco.

Hausmann, Ricardo, Ugo Panizza and Ernesto Stein, 2001, "Why Do Countries Float the Way They Float?", Journal of Development Economics, 66(2), pp. 387-414. http://dx.doi.org/10.1016/S0304-3878(01)00168-7

International Monetary Fund (IMF), 2004, Sovereign Debt Structure for Crisis Prevention, Washington, DC: International Monetary Fund.

International Monetary Fund (IMF), 2010, Greece: Staff Report on Request for Stand-By Arrangement, IMF Country Report, No. 10/110, Washington, DC: International Monetary Fund. 
International Monetary Fund (IMF), 2013, Greece: Ex Post Evaluation of Exceptional Access under the 2010 Stand-By Arrangement, IMF Country Report, No. 13/156, Washington, DC: International Monetary Fund.

International Monetary Fund (IMF), 2014, Greece: Fifth Review under the Extended Arrangement under the Extended Fund Facility, IMF Country Report, No. 14/151, Washington, DC: International Monetary Fund.

International Monetary Fund (IMF), 2015a, Republic of Croatia: 2015 Article IV Consultation - StaffReport, IMF Country Report, No. 15/163, Washington, DC: International Monetary Fund.

International Monetary Fund (IMF), 2015b, Global Financial Stability Report, Washington, DC: International Monetary Fund.

Jeanneau, Serge and Camilo E. Tovar, 2007, "Latin America's Local Currency Bond Markets: An Overview”, BIS Papers, No. 36, June, Basel: Bank for International Settlements.

Krugman, Paul R., Kenneth S. Rogoff, Stanley Fischer and William J. McDonough, 1999, "Currency Crises", NBER Chapters, in Martin Feldstein, ed., International Capital Flows, pp. 421-466, Chicago, IL: University of Chicago Press.

Kunovac, Davor, 2013, "The Borrowing Costs of Selected Countries of the European Union - the Role of the Spillover of External Shocks", Working Papers, No. 38, August, Zagreb: Croatian National Bank.

Lam, Raphael W. and Kiichi Tokuoka, 2011, "Assessing the Risks to the Japanese Government Bond (JGB) Market", IMF Working Papers, No. 11/292, December, Washington, DC: International Monetary Fund.

Levinsohn, James A., Steven T. Berry and Jed Friedman, 2003, "Impacts of the Indonesian Economic Crisis. Price Changes and the Poor", NBER Chapters, in Michael P. Dooley and Jeffrey A. Frankel, eds., Managing Currency Crises in Emerging Markets, pp. 393-428, Chicago, IL: University of Chicago Press. http://dx.doi.org/10.7208/chicago/9780226155425.003.0013 
Mihaljek, Dubravko, 2009, "Globalna financijska kriza i fiskalna politika u Središnjoj i Istočnoj Europi: hrvatska proračunska odiseja u 2009. godini”, Financijska teorija i praksa, 33(3), pp. 241-276.

Mody, Ashoka and Damiano Sandri, 2011, "The Eurozone Crisis: How Banks and Sovereigns Came to be Joined at the Hip", IMF Working Papers, No. 11/269, November, Washington, DC: International Monetary Fund.

Radošević, Slavo and Andrew Rozeik, 2005, "Foreign Direct Investment and Restructuring in the Automotive Industry in Central and East Europe", Working Paper No. 53, March, School of Slavonic \& East European Studies, London: University College London.

Reinhart, Carmen, Kenneth Rogoff and Miguel A. Savastano, 2003, "Addicted to Dollars", NBER Working Paper, No. 10015, October, Cambridge, MA: National Bureau of Economic Research.

Rohatinski, Željko, 2015, Ogledi u realnom vremenu (2000.-2014.), Zagreb: EPH Media.

Wyplosz, Charles, 2013, "The Eurozone Crisis and the Competitiveness Legend", Asian Economic Papers, 12(3), pp. 63-81. http://dx.doi.org/10.1162/ ASEP_a_00238

Zoli, Edda, 2013, "Italian Sovereign Spreads: Their Determinants and Passthrough to Bank Funding Costs and Lending Conditions", IMF Working Papers, No. 13/84, April, Washington, DC: International Monetary Fund. 